\title{
Meu Paciente: Reflexão Sobre o Conceito de Violência Simbólica Infligida no Cuidado com Os Usuários dos Serviços da Saúde
}

\author{
Zanatta, Aline Bedin; Lucca, Sergio Roberto de \\ Universidade Estadual de Campinas- Unicamp — alinezanatta@yahoo.com.br
}

Introdução: a dimensão simbólica é essencial ao ser humano, ao simbolizar, pode interpretar e representar a sua própria vivência de maneiras distintas, relacionando-se ao meio e aos grupos que pertence. As formas dominantes de cultura buscam manter sua posição privilegiada, apresentando seus bens culturais como naturalmente superiores aos demais. Através do controle do capital simbólico que os dominantes impõem aos dominados seus valores culturais, as hierarquias, as relações de dominação, fazendo-os percebê-las como legítimas. o poder simbólico permite obter o equivalente daquilo que é obtido pela força (física ou econômica), graças ao efeito específico de mobilização que provoca. Objetivos: Será abordado a violência simbólica segundo Bourdieu, nas relações entre profissionais da saúde e os usuários dos serviços da saúde. Metodologia: Ensaio teórico reflexivo com revisão da literatura. Resultados: ao observar as relações entre profissionais de saúde e paciente, percebe-se que os profissionais impõem e legitimam o saber médico científico, como a uma forma de conhecimento dominante e exterior ao indivíduo, desvalorizando os saberes acumulados dos pacientes e colocando-os na função de receptores passivos dos procedimentos e decisões realizados sobre seus corpos. o sujeito é um mero objeto da prática da medicina cientifica. Os usuários dos serviços de saúde estão acostumados com essa relação de imposição entre eles e os profissionais da saúde: imposição do diagnóstico, do poder que o profissional tem para manusear seu corpo, despindo-o, administrando medicamentos, vendo sua nudez, dando-lhe alimentos, tirando sua privacidade, exercendo controle sobre suas ações - muitas vezes controle demasiado e desnecessário- utilizando-se de sua posição de superioridade perante um paciente doente, debilitado ou necessitando dos serviços de saúde. Isto demonstra uma relação de poder simbólico, e muitas vezes de violência simbólica, onde o paciente não pode reclamar, não querer, não fazer ou mesmo exprimir o que sente. Inclusive, muitas vezes até manifestações de dor são reprimidas. Segundo o conceito de violência simbólica, o paciente não se percebe como sendo vítima de um sistema opressor que o trata como um mero objeto de intervenção sem capacidade de decisão. Conclusões: a violência simbólica nos serviços de saúde está expressa principalmente na imposição do saber médico-científico como único e imutável, na desvalorização do usuário, dos seus desejos, vontades, opiniões e pode aparecer também como forma de descriminação, preconceito e atendimento diferenciado como no caso de grupos sociais estigmatizados pela sociedade e consequentemente pelo serviço. Faz-se necessário a conscientização sobre esse tipo de relação de dominação entre os profissionais da saúde e os usuários do serviço, que devem ser respeitados, acolhidos e valorizados nos serviços de saúde como seres humanos e vistos como atores sociais e sujeitos donos de suas vidas e vontades.

Zanatta, Aline Bedin; Lucca, Sergio Roberto de. Meu Paciente: Reflexão Sobre o Conceito de Violência Simbólica Infligida no Cuidado com Os Usuários dos Serviços da Saúde. In: Anais do Congresso Internacional de Humanidades \& Humanização em Saúde [= Blucher Medical Proceedings, num.2, vol.1]. São Paulo: Editora Blucher, 2014. ISSN 2357-7282

DOI 10.5151/medpro-cihhs-10442 